\title{
Articles
}

\section{SOME THOUGHTS ON NOMINAL CONVERGENCE, ITS DRIVERS AND DETERMINANTS FOR THE NEW EU MEMBER STATES PREPARING THE EURO ADOPTION}

\author{
Václav Žd'árek*
}

\begin{abstract}
:
The article analyses the process of nominal convergence of the new EU member states (NMS) with particular attention paid to some applied and theoretical aspects, which may have impact on the process of the euro adoption. Chapter two addresses selected theoretical and methodological issues connected with the International Comparison Project (ICP). It discusses determinants and influences affecting price level convergence and some issues that have set off new trends, such as the globalization or process of the on-going European integration. This chapter also presents a brief summary of the main trends of price convergence observed by focusing on changes of comparative price levels (CPL) for various disaggregated items of GDP. It also deals with potential issues and problems arising in this context. Chapter three is aimed at an empirical verification of price convergence and at a search for main driving factors using data for the NMS and the old EU member states over 11 years (1995-2006). There are some differences in results depending on the applied econometric method. The most important determinants of price level are GDP and population, the openness and public finance's indicators are not significant. The last section summarises the main findings.
\end{abstract}

Keywords: nominal and real convergence, relative price level, international comparisons, law of one price, new EU members, globalization

JEL Classification: E31, F15, F31, P22, O11

* Centre for European Studies, University of Economics and Management, Prague, University of Economics, Prague.

The author thanks R. Vintrová from the CES VŠEM Prague for comments on an earlier version and an anonymous referee and the participants of the 7th Conference of the European Economic and Finance Society (EEFS) at the University of Economics in Prague for their valuable comments and suggestions, gratefully acknowledges financial support from the grant of the Czech Grant Agency No. 402/06/0209. The author alone is responsible for errors and omissions that may remain. 


\section{Introduction}

The last two rounds of the European Union enlargement taking place in May 2004 and January 2007 were important moments for the new EU Member States (NMS) ${ }^{2}$ on the road to the adoption of the common European currency. The following steps are associated with meeting the Maastricht convergence criteria, which include aspects of nominal and real convergence. The most discussed topics are related to the process of nominal convergence. One of the possible explanations may be that these countries will become a part of the euro area which might trigger adjustment process effectively influencing the price stability of the existing members of the euro area. As a result, there might be a narrower room for manoeuvres of the European Central Bank (ECB). On the other hand, the process of integration of NMS and other European countries (EU-15) and in particular of removal of trade barriers might have an impact on the on-going process of equalisation of national prices (because of increased competition, reduced risk, etc.). Therefore, one might expect that this could be reflected in price data.

While some of the NMS have a plan for introducing the euro and a preliminary date for joining the euro area has been set, there are another NMS that have just introduced the euro. ${ }^{3}$ The final decision on adopting the common currency will probably be made within a couple of next years. The relevant countries will also be assessed by EU authorities as to whether they meet the determined Maastricht convergence and other criteria for entering fully the third stage of the Economic and Monetary Union (EMU). There have been a lot of analyses focusing on the nominal and real convergence of economies including comparison with countries which have adopted the euro so far (see for example De Grauwe and Schnabel, 2005). Even though the topic still seems to be relevant and interesting for researchers due to a large number of open questions and newly arising issues (for example experience with introducing the euro in selected old EU (catching-up countries) and new member states, in particular in case of Slovenia or Slovakia).

Studies of nominal convergence have shown that the process of nominal (price) convergence is gradual and significant in many (catching-up) EU countries (see ECB, 1999; Faber and Stockman, 2007; Dreger et al., 2007), in particular in connection with tradable goods. However, this trend is not as significant in the case of non-tradable

2 We focus on the new EU member states including the new entrants from 2007 (i.e. including Bulgaria and Romania), except for Cyprus and Malta. If we mention another group than the whole, we are going to use the abbreviation NMS with an appropriate number of countries, i.e. for example NMS-10 (without Cyprus, Malta) or NMS-8 (without two new entrants Bulgaria and Romania), etc. Many implications in this article are relevant only for the NMS-4 states, i.e. the Visegrad group and in some manner for the Baltic States. The new EU member states from Central and Eastern Europe have undergone transformation from central planned economies to market economies. As a result, they share a large number of common characteristics in connection with the convergence process. In addition, Slovenia has certain specifics in this regard since it was linked to Western economies prior to the collapse of the former Yugoslavia and did not introduce a rigid system of central planning.

3 The first NMS which introduced the euro were Slovenia (2007), Cyprus and Malta (2008) and Slovakia which joins the euro area in 2009. Some states have declared the date for the euro adoption too (the Baltic States: 2010 (Lithuania), 2011 (Estonia) and 2012 or 2013 (Latvia)) or this issue is still being discussed (Poland, the Czech Republic) or temporarily postponed (Hungary). The only country which has declared an official date is Romania (2014), see EC (2007). 
goods and goods or services which are subject to national taxation or regulation. On the other hand, certain studies do not confirm price convergence (Lutz, 2003, 2004) or convergence of inflation rates (Buseti et al., 2006) even in the case of the euro area. ${ }^{4}$ This would suggest the existence of obstructions in the EU that should have been eliminated during the process of the European integration. However, the studies carried out by the European Commission (EC, 2006) reveal a number of problems in this context, implicating the possibility and potential for further price convergence in the EU countries.

However, significant changes in convergence process cannot be expected within just a few years. The economic standard will continue to grow at a slower pace over the next few years as the NMS approach the level of the European Union. Price (wage) levels as well as labour productivity should grow faster compared to the current rate to ensure smooth progress of integration in the euro area. These changes should arise from adjustment that does not lead to a high price (and subsequently wage) rise without the corresponding growth of labour productivity. Potential price and wage spiral would only ultimately lead to a fall in the real living standard and halt the convergence process. This is why the NMS cannot be expected to reach the average European economic standard sooner than in a few decades. ${ }^{5}$ After all, even the less developed countries that joined the EU in the 1980s have not reached the economic or price level of other developed EU countries to this day. ${ }^{6}$

The rest of the article is organized as follows: Section 2 addresses selected theoretical and methodological issues associated with international comparison and determinants and influences affecting price level convergence. This section also presents a brief summary of the main trends of price convergence measured by focusing on changes of price levels for various disaggregated items of GDP and deals with potential issues and problems. Section 3 is aimed at an empirical verification of price convergence and search for main driving factors of it in NMS by using data for the NMS and consequently for NMS and old EU member states. Finally, Section 4 summarises the main findings of this article.

\section{Some Theoretical Considerations}

Nominal convergence describes approximation of nominal (therefore chiefly price-related) values between countries to a certain level that is either unchanged or varies over time. Price convergence issues are very pressing in the case of new EU

4 Based on different price indices: prices of new cars in Europe, The Economist's BigMac index, prices of selected commodities (monitored by The Economist) and index of world prices monitored by UBS. The UBS index is based on prices in selected cities all over the world. The latest data set is available for 2006 and covers 71 cities (35 European, 33 EU members and one from Norway and Ukraine) and 122 items of goods and services see UBS (2006).

5 There have been a large number of studies of real convergence process in the NMS. The traditional approach based on OLS estimates of beta and sigma convergence can be found for example in the work of Slavík (2007), detailed view on sources of GDP growth and convergence of the NMS to EU-15 for example in Hájek (2008).

6 Other issue is whether the countries has converged to a common higher level or the more advanced countries has slowed down which has resulted in a lower common level. 
members in connection with preparations for accepting the single European currencythe euro. Determining the parity (conversion) ratio will have far-reaching consequences for the entire real economy. Once the single currency has replaced individual national currencies, one of the available transmission mechanisms used in the process of nominal convergence will be eliminated. ${ }^{7}$

There is a lack of consensus regarding the definition of the term nominal convergence among individual authors. At least three different views on this process exist. Nominal convergence can be understood as follows:

1. Convergence of prices (narrow concept, price convergence, see for example López-Salido and Quirós, 2006; Wolszczak-Derlacz, 2008);

2. The second concept involves nominal convergence as convergence of all nominal values, i.e. prices, wages, pensions, etc. (wide definition; for an application see for example Vintrová, 2007);

3. The third approach (perhaps the most commonly used definition) links nominal convergence to the Maastricht convergence criteria that the relevant country is required to meet before accepting the single currency (see for example Schadler et al., 2005; Dobrinsky, 2006), or individual criteria (see Kočenda et al., 2006).

The following text uses the term nominal convergence according to the first concept or directly the term price (level) convergence, which is understood as a synonym for the purposes of this text. This means that we focus on one of the individual processes and apply a similar approach as for example Backé et al., 2003; Allington et al., 2005). Examination of the relationship between convergence of price levels in the euro area and NMS is the starting point of the debate on the course of the convergence process.

Numerous studies have focused on the issue of price convergence for NMS (see Čihák and Holub, 2001, 2003; Nestić, 2005; Dreger et al., 2007) or for the euro area looking at the general price index and the influence of the euro adoption (see for example ECB, 2005; Engel and Rogers, 2004) or for some items as a part of PPP/LOOP debate (literature review see for example Crucini et al., 2005; Wolszczak-Derlacz, 2008) or for individual items (cars) see for example Lutz (2004), Goldberg and Verboven (2005). However, most of the papers focus on nominal convergence with regard to the fulfilment of the Maastricht convergence criteria. These are for example studies that focus on new member states and mostly discuss potential consequences arising from strict adherence to the Maastricht criteria in NMS (see Dobrinsky, 2003, 2006; Kočenda et al., 2006). While the results obtained from evaluation of nominal convergence (fulfilment of the convergence criteria) show convergence among NMS, the results obtained from price convergence show more contradictions (see Vintrová and Žd'árek, 2007).

Great attention is paid to discussion, tests and estimates of the impact of the Balassa-Samuelson effect (BS effect) ${ }^{8}$ for EU-15 countries (or the euro area) and for

7 A brief summary of different approaches of individual authors to the theoretical definition of real and nominal convergence is presented for example in the work of Dobrinsky (2003); Žd'árek, Šindel (2007).

8 Sometimes referred to as the Balassa-Samuelson effect or the Harrod-Balassa-Samuelson effect or the Ricard-Harrod (-Balassa-Samuelson) effect, see Égert, (2003) or an in-depth view in Viner (1937). 
NMS (due to its importance and problems with meeting the Maastricht convergence criteria for price and exchange rate stability, see Dobrinsky, 2006) in connection with price convergence. The BS effect is responsible for the so-called structural inflation. Estimates of its significance differ greatly, however, they are ambiguous and depend on the approach of individual authors (model type) and the econometric model applied in the analytical process (Égert, 2003). The most commonly quoted studies include (Mihaljek, Klau, 2003), which estimates the impact of the BS effect on the inflation rate between 0.1 and 2.0 p.p. (on the average inflation rate according to countries); this should not pose any significant problems in relation to the fulfilment of the Maastricht convergence criteria. However, the latest estimates (Brook, 2005) point out the importance of the influx of foreign direct investment (FDI) to NMS-10 during the 1990s and at the beginning of the new century which indirectly reflect in the increasing estimated significance of this effect. The BS effect therefore should not be ignored but its importance and its impact should not be overestimated at the same time.

\subsection{Real Convergence and Price Level}

It has been observed that the average price and economic level are closely dependent because of existence of differences in prices of non-tradable goods and services in case of developed and developing countries (see Kravis, Lipsey, 1988). In addition, price adjustment in an open economy is determined to a significant extent by autonomous factors whose strength arises from the share of administered prices in the relevant economy. It is expected that real convergence (catch-up) will raise price level at a very similar pace. Given the fact that there are differences between economic and price levels in new EU countries, the uncertainty about speed and magnitude of these processes may result in difficulties or threats during the time in ERM II or later (see for example Pazour, 2006). However, development of the price level therefore needs to be considered in the context of price differences between tradable and non-tradable goods and administered (regulated) items.

Prices of tradable goods are set (pinned down) in principle by international competition and the influence of domestic conditions is relatively insignificant (depending on the share of non-tradable component reflecting the selling structure for particular good). Therefore, the prices of some of these commodities may be at an international level (LOOP/PPP may hold), while the other prices may be above or below this level. Their development may be influenced by many other factors and these prices may not change much although different movement arising from price divergence will be observed in other prices. It is important that the price convergence displays differentiated development in principle reflecting different development in tradable and non-tradable groups (or sub-groups) of goods, inputs and outputs because only then the competitiveness of domestic producers can be sustained on a long-term basis.

Non-tradable goods have a low price level arising from the past conditions and this level grows very slowly as the economic standard and the wage level increases. This growth should not be irrespective of development in the labour productivity as this could lead to consequences identical to those experienced currently by the states of the former East Germany. Long-term adjustment process can be expected and it is impossible to reasonably predict that the $\mathrm{CR}$ will successfully reach a level similar to 
that of other EU countries. After all, even other EU countries display significant deviations in this area many years after their accession.

The issue of a very low or very high price level in economy (in comparison to the economic level) is often discussed in literature. Although opinions of individual authors differ, certain factors that significantly influenced the price level in economy can be listed (see Skořepa, 2001; Čihák, Holub, 2003; Égert, 2007):

1. a (large) devaluation of domestic currency at the onset of the transformation process;

2. an imperfect competition (for example existence of monopolist competition on markets with tradable goods, such as sophisticated products with emphasis on their quality rather than price, ${ }^{9}$ strategic pricing ${ }^{10}$, etc.);

3. distorted price relations (relative prices) including impact of direct and indirect taxes, subsidies and domestic price regulations;

4. the speed and cost of arbitrage (that is not a temporary price difference because it is related to obstacles to arbitrage between countries);

5. a share of a sector producing non-tradable goods and services and a share of non-traded inputs in purchased goods and services;

6. the statistical illusion (mismeasurement) associated with international comparisons of prices and volumes where completely identical items may not exist in the compared countries, in particular clothing or foodstuff can be used as a good example of this phenomenon).

The last three factors seem to be currently very significant. As the Section 2.2 addresses the issue of arbitrage and tradability, we will now focus on the last factor. When a particular representative is not available in the compared economies, expert qualitative modifications are made in the case of a substitute representative (for example a corresponding Czech item needs to be modified and this difference is valuated according to the cost of its creation). A specific problem occurs in the case of branded goods. The quality of this estimate remains a question and despite that, the price is hypothetical and may therefore differ from the actual price achievable on the market. An alternative explanation is based on consideration of the importance of non-tradable goods in the economy. However, the low price level is primarily caused by the impact of tradable and non-tradable goods and their weight in the economy.

In addition, the on-going successful process of real convergence (GDP p.c.) in the relevant country resulting in an adjustment to consumer demand structure towards a higher share of non-tradable goods has a very different impact. The price elasticity in the case of these goods tends to be higher and this ultimately leads to a faster growth in prices.

The price development (nominal convergence) in NMS-5 (or more generally in NMS-8, NMS-10) countries is estimated as a long-term process similar to real convergence. However, if the rate remains stable, the sector producing non-tradable goods will create positive inflation differential and its extent will depend greatly on the development in prices of tradable goods. Moving from the macroeconomic level to

9 Lower quality of products would lead to compensatory pressure on export prices depending on demand elasticity.

10 In general, any other kind of behaviour of firms which can cause an imperfect exchange rate pass-through. 
a more detailed structure of commodity groups (individual items) and assessing the structure of their relative prices and their changes in time would be necessary for a more in-depth analysis. This was the case in the results of the international comparison for the period from 1996 to 2001 (2003), see for example Čihák, Holub (2005).

\subsection{Has the Convergence Process Changed?}

Contrary to simple assumptions, a variety of goods and services (commodities) cannot be traded internationally and these are produced and consumed in the national economy. They are referred to as the non-tradable commodities. This situation influences not only pricing and output structure, but also restricts possible options for stabilising policies.

Non-tradable commodities (a variety of services can be used as an example) also directly influence the structure of supply and demand for these commodities (a growth in the supply cannot be compensated by export), and the prices may differ significantly between individual countries even over a long-term period. ${ }^{11}$ Their existence is a reason for limited applicability of models (for example foreign exchange rate) using purchasing power parity.

Before we attempt distinguishing tradable goods and services from non-tradable ones, we will briefly discuss two important determinants influencing this distinction. Firstly, there are transport costs posing natural obstacles. If these costs are high (often considered in relation to a single unit), they restrict tradability of the relevant goods. On the other hand, technological development may reduce these costs (for example development of modern information and telecommunication technologies, ICT) and thus ensure tradability of a range of services. ${ }^{12}$ The second determinant is connected with customs and other barriers (customs duty, quotas, regulations, etc.).

Standard classification (UN SITC), which defines nine categories, can be used successfully to distinguish tradable goods and services in practice. The first three categories can be considered as fields producing tradable commodities, while the remaining categories tend to be non-tradable (construction industry, services, national transport, such as train or underground railway services). Agricultural commodities may be an exception (these are non-tradable owing to the two reasons discussed above), as well as certain services, for example construction services, which may become tradable (literature mentions an example of Korean companies that carried out construction work in Near and Middle East during the 1970s (see Larraín, Sachs, 1993) and do so again; after all, this situation may also occur once the barriers within the extended European Union are removed).

Certain goods and services are classified as tradable, others as non-tradable. However, indicating the exact borderline is very difficult. Traditional systems and

11 The existence of cheap office and storage space in Asian or African countries does not allow their direct use by for example Czech producers and their prices may differ from the prices in Prague or anywhere else in the world by tens of percent or more. However, significant differences appear also in the case of tradable goods, see below.

12 Banking services, insurance services, data processing, etc. can be used as an example of services provided to many companies in various parts of the world according to the cost-based advantage. This does not apply to specific services with high demands on the quality, supervision, etc. 
viewpoints change with gradual changes that can be observed almost on a daily basis. The conventional division into goods = tradable and services $=$ non-tradable is currently not only influenced by the question what is and what is not a service, but also by the fact that traditional services, such as construction, hairdressing, and so on are tradable, while real estate is usually seen as non-tradable. ${ }^{13}$

In the background of this discussion, there is a law of one price, according to whichproviding no limiting factors exist (insufficient competition, transport and other transaction costs, and so on) - an identical commodity should have an identical price in the domestic and foreign economies when converted to the same currency (territorial, commodity and time arbitrage is excluded), for more details on this issue see for example Officer (1976). ${ }^{14}$ A rate determined by purchasing power parity (in the absolute value) is constructed on this basis (see below).

If these conditions are not met, this in reality leads to the option of carrying out arbitrage and this should theoretically eliminate differences in prices. However, as the transaction costs are not zero, this usually merely reduces the price difference to a level where arbitrage is no longer worthwhile (see Figure 1). If the price of a commodity ranges within $\left\langle p_{B A} ; p_{A B}\right\rangle$, arbitrage is excluded (excessively high costs). ${ }^{15}$ Arbitrage in the case of prices falling within the highlighted interval is viable for entities depending on their situation (that is selective arbitrage). Furthermore, the arbitrage process as such reduces the price difference for the relevant commodity and thus practically eliminates the potential opportunity for carrying out arbitrage. This shows that determining an exact borderline between tradable and non-tradable items is virtually impossible.

Figure 1

\section{Simple View on the Issue of Tradability}

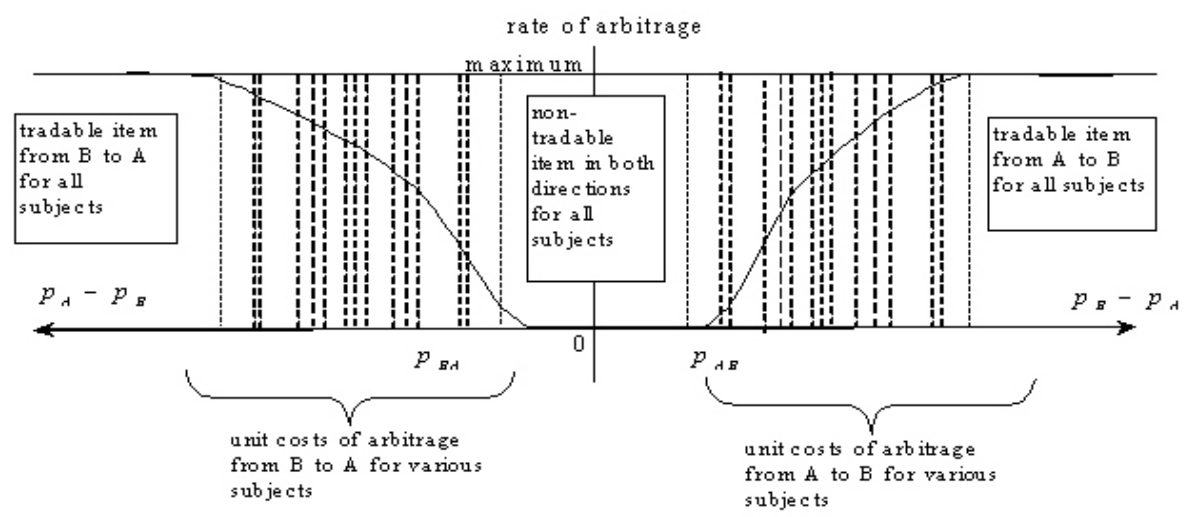

Source: Skořepa (2001), p. 353, author's own adaptation.

13 An example of tradable and non-tradable items for selected product groups in see for example Allington et al. (2005).

14 The applicability of this assumption in the strict version requires exchange rate determination.

15 Taylor and Taylor (2004) in this context mention the iceberg effect because certain commodities cease to be effectively tradable because they are transported and transaction costs are typically proportionate to the distance of transport in addition to the fixed costs of the transporting entity. Delays of deliveries between individual locations may represent yet another issue. 
Different labour productivity (lower in the non-tradable sector) is the main reason behind lower price levels in less developed countries. As prices of tradable commodities are determined by worldwide prices, lower productivity means lower wages. However, higher productivity in the tradable sector leads to lower prices. An alternative approach is based on the availability of individual factors in the relevant country - production of labour-intensive products (usually non-tradable) is less costly. The price level in the economy is determined by lower prices of non-tradable, but also tradable commodities, which almost always use non-tradable commodities in their production or distribution.

\subsection{A Fresh Look at the NMS Data}

The NMS have shown good economic performance resulting in strong catching-up process (real convergence) which can be justified by looking at the actual economic data. Other side of this process is reflected by nominal convergence, i.e. increasing price level of GDP. Despite favourable development in recent years, there is still a huge discrepancy between price level for GDP in NMS and even the euro area average - the current levels (2006) ${ }^{16}$ range from 37 per cent (Bulgaria) to 71 per cent (Slovenia), see Table 1. The price level of catching-up (Mediterranean) EU members is also below the euro area average (CPL for GDP, but for example for household consumption too). The lower the price level (disaggregated) we analyse, the bigger the potential bias of price level for the item might be. ${ }^{17}$ We choose some of the items of consumption to show the differences - the last three columns show price levels of the main components of actual individual consumption and can be understood as a good approximation in relation to the issue of tradability (see below) ${ }^{18}$ It also confirms the above stated idea that not only price levels of goods are lower in NMS with lower GDP p.c. in relation to the euro area average, but also the price levels of services. For example item health which is made of various services ${ }^{19}$ has with price levels ranging from 24 (Bulgaria) to 66 per cent (Slovenia) of the euro area average (almost the same pattern is in case of education which is not showed). Similar difference can be observed in Mediterranean countries like Greece or Spain too. ${ }^{20}$ (These items are also used by calculating the main components of $\mathrm{HICP}^{21}$ ) The convergence process has taken place in recent years after

16 The figures for 2007 are for most countries preliminary and show few changes or are not available.

17 The problems of interpretation of ICP results in this context see OECD (2008) or WB (2007).

18 Another 'rough and quick' approach when assessing the progress of price convergence may be to have a look at the coefficient of variations prices of goods and services which have substantially declined over recent years, see for example Žd'árek and Šindel (2007).

19 This item consists of goods and appliances, however, their magnitude is not so large and therefore, and their influence on the price level is not able to change the price level too much.

20 From our point of view it seems to be better that using some other items, such as non-durable goods which cover a wide range of different products with similar possibilities of use. Nevertheless, this approximation presents a higher level of disaggregation.

21 Due to the change in methodology of the national accounts during the 1990s (from ESA 1968 to ESA 1995), the most of the time-series for detailed CPL items are available 1999 onwards which makes it difficult to compare changes of items over longer time span. 
transformation decline at the beginning of the 1990s. The only exception is Slovenia with relative high price level. ${ }^{22}$

Table 1

Basic Facts for NMS (EU-12 = 100)

\begin{tabular}{|l|c|c|c|c|c|c|c|c|c|c|c|c|}
\hline & \multicolumn{2}{|c|}{ GDP p.c. } & \multicolumn{2}{c|}{ CPL for GDP } & \multicolumn{2}{c|}{ HFCE $^{1)}$} & \multicolumn{2}{c|}{ Food $^{2)}$} & \multicolumn{2}{c|}{ Communications $^{\mathbf{3}}$} & \multicolumn{2}{|c|}{ Health } \\
\cline { 2 - 13 } & $\mathbf{1 9 9 5}$ & $\mathbf{2 0 0 6}$ & $\mathbf{1 9 9 5}$ & $\mathbf{2 0 0 6}$ & $\mathbf{1 9 9 5}$ & $\mathbf{2 0 0 6}$ & $\mathbf{1 9 9 9}$ & $\mathbf{2 0 0 6}$ & $\mathbf{1 9 9 9}$ & $\mathbf{2 0 0 6}$ & $\mathbf{1 9 9 9}$ & $\mathbf{2 0 0 6}$ \\
\hline CZ & 64 & 71 & 36 & 59 & 39 & 60 & 51 & 66 & 68 & 126 & 25 & 43 \\
HU & 44 & 59 & 42 & 58 & 41 & 58 & 53 & 68 & 81 & 90 & 26 & 44 \\
PL & 37 & 47 & 41 & 57 & 44 & 61 & 50 & 64 & 115 & 107 & 31 & 38 \\
SI & 64 & 80 & 69 & 72 & 70 & 73 & 90 & 84 & 58 & 79 & 59 & 66 \\
SK & 41 & 58 & 38 & 54 & 37 & 57 & 51 & 64 & 71 & 112 & 25 & 42 \\
\hline EE & 31 & 62 & 35 & 60 & 39 & 65 & 68 & 73 & 78 & 84 & 28 & 44 \\
LT & 29 & 51 & 25 & 52 & 29 & 55 & 54 & 62 & 89 & 66 & 26 & 40 \\
LV & 27 & 49 & 31 & 55 & 36 & 59 & 61 & 67 & 121 & 103 & 23 & 36 \\
\hline BG & 28 & 33 & 24 & 37 & 31 & 44 & 51 & 54 & 64 & 101 & 16 & 24 \\
\hline RO & 23 & 35 & 31 & 49 & 29 & 56 & 48 & 68 & 77 & 91 & 18 & 29 \\
\hline
\end{tabular}

Note: 1) HFCE - Household final consumption expenditure. 2) Food and non-alcoholic beverages. 3) Communication. The relative price levels are based on ESA 1995 aggregates. The items: food and non-alcoholic beverages, communication and health are the main items by disaggregating actual individual consumption.

Source: EUROSTAT (2008, 2008a), National Accounts (downloaded in August, 2008), author's own calculations.

By looking at the data for countries all over the world, two facts are visible. ${ }^{23}$ Firstly, the less developed economies show lower real GDP per capita which is connected with lower price level for GDP (see Figure 2). Secondly, the developed and developing countries tend to show higher price level that real GDP per capita. If the purchasing power parity (PPP or generalized law of one price) does hold true, the prices of goods and services should be the same around the world. The smooth functioning of PPP in economic reality is disrupted by a wide range of economic and non-economic factors. One of the most important factors is low price level of services (non-market). While prices for goods tend to be close to the parity (given by PPP) with exceptions, the prices of services are more dispersed due to wages differences (and estimation method).

22 Stagnating Slovenian price level was due to a large number of factors; inter alia state regulations of prices and wages (owing to agreements between labour unions and government), limited scope of competition and exchange rate policy.

23 For example by examining the data from the latest round of International Comparison Project 2003-2006, see WB (2007). 
Figure 2

Relationship between Comparative Price Level for GDP and GDP p.c., 2007, $(E U-12=100)$

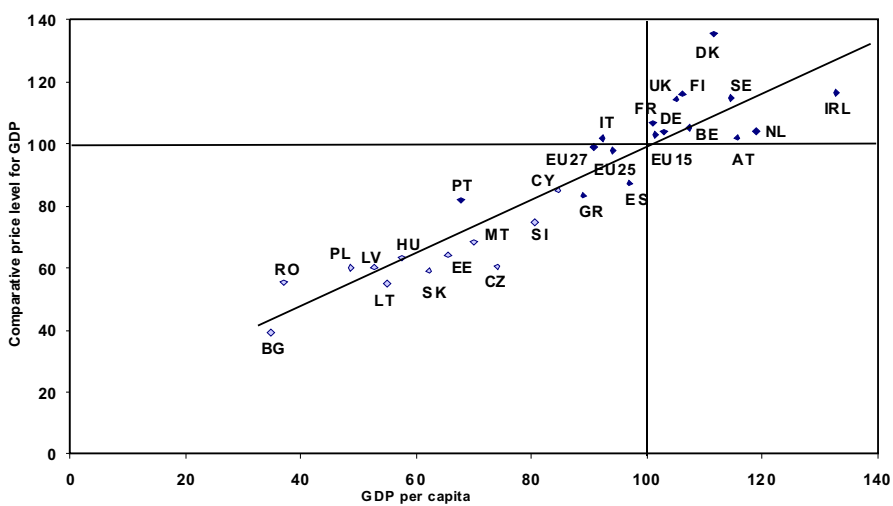

Note: EU-15 = the old EU member states. The selected characteristics of the showed regression line are given in text below.

Source: EUROSTAT (2008a), author's own calculations.

The very obvious example of the well-known fact that the changes of CPL and GDP are not proportional (simple relationship based on GDP p.c. and CPL for GDP has slope around 0.9, see for example Čihák, Holub, 2003), is given by the Figure 3.

Figure 3

Dynamics of CPL for GDP and GDP p.c., NMS (EU-12 = 100), 1995-2007

Note: CPL and GDP p.c.

1995-1998 for

Romania are not available.

Source:

EUROSTAT

(2008a), author's own calculations.
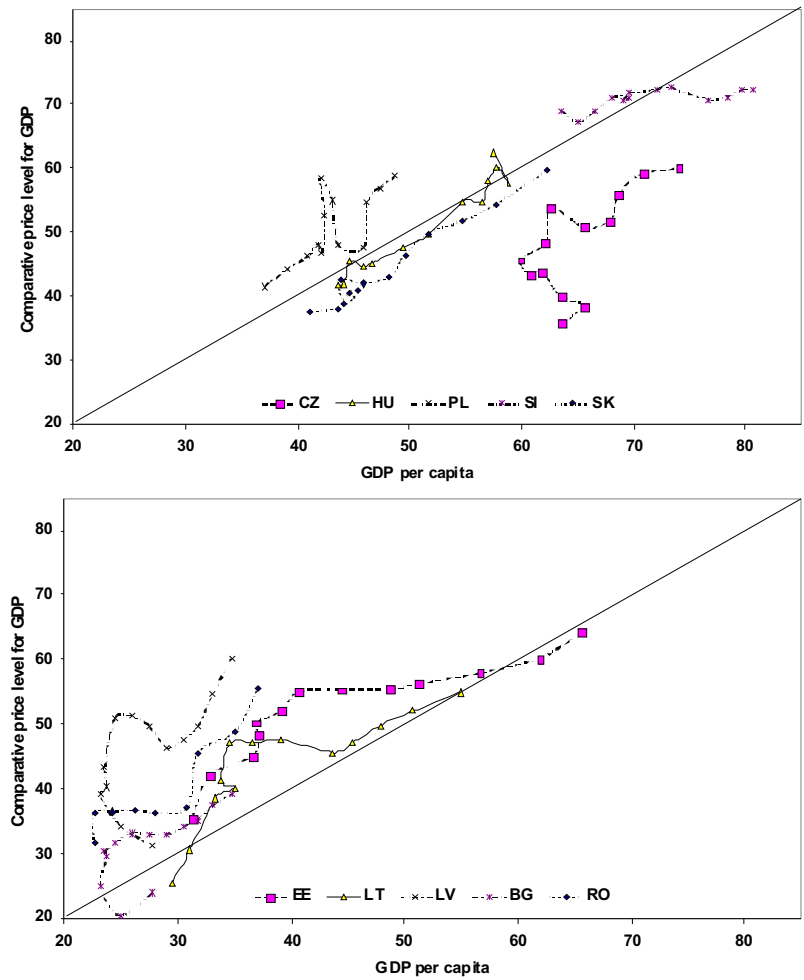


\subsection{Price Level vs. Rate of Inflation}

The relationship between changes in comparative price level and inflation are not so clear as one would suppose (see Figure 4). To start with, one must distinguish between short-term influences and long-term ones (see Égert, 2007). The former ones (for example phases of economic cycle) work primarily upon the rate of inflation and their impact on price level is ambiguous. The very similar influence is the impact of long term exchange rate development - it depends on the strength and the completeness of pass-through. If it is incomplete, development of exchange rate will not work upon inflation, but through movements of relative price level.

Figure 4

Influences on Price Level and Rate of Inflation

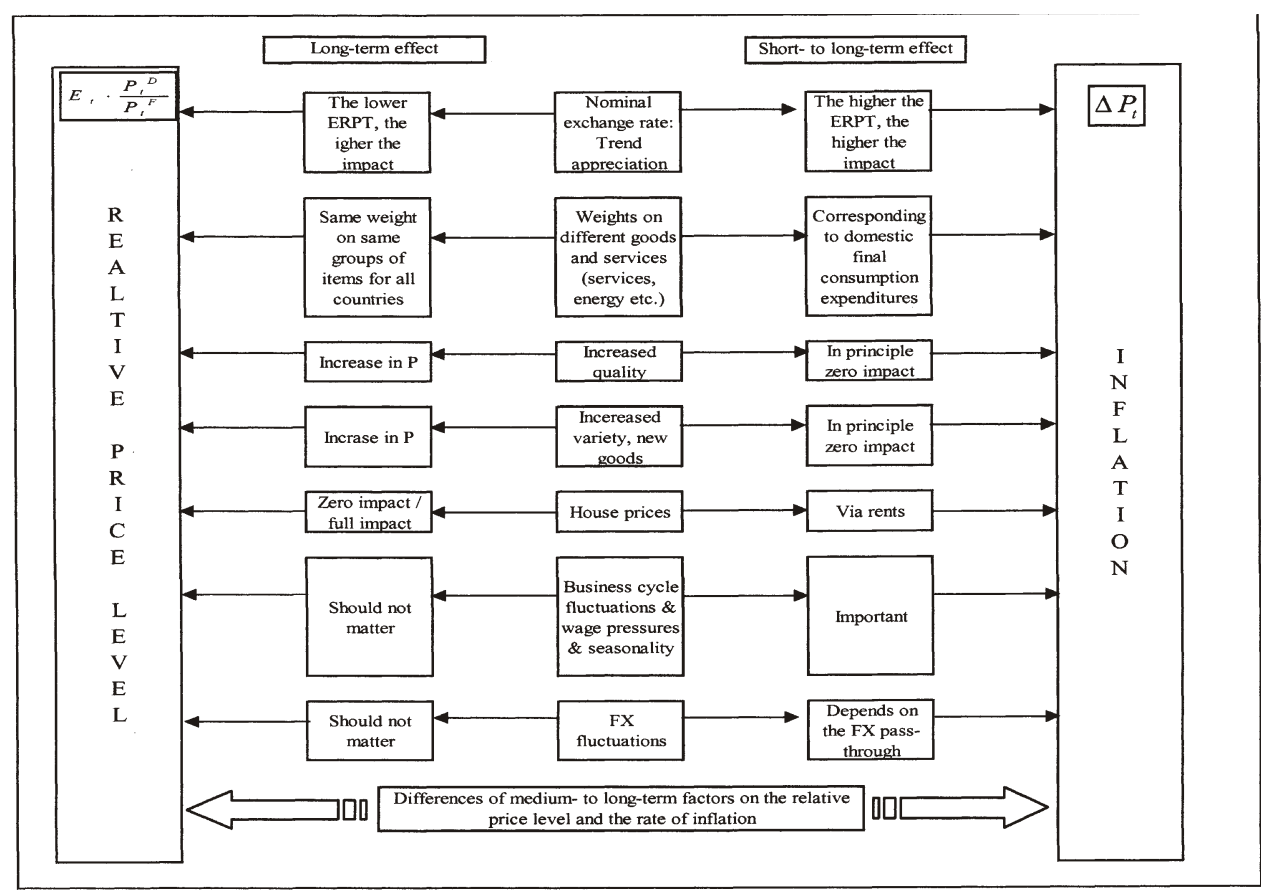

Note: FX - exchange rate, ERPT - exchange rate pass-through.

Source: Égert (2007), p. 38, author's own adaptation.

One of the main sources of differences are the weights - inflation is calculated using given (fixed) weight based on household expenditures, weights for ICP are comparable for some items, but some weights are different (CPI, HICP indices do not cover price changes of these items). Therefore, inflation rate and change in price level are relatively independent measures, one can change while the other stagnates and vice versa. For transition and catching-up countries (NMS) does hold that their inflation basket put less weight on services (like telecommunications) and market goods (various household 
appliances) and more on regulated (administered) goods and services, such as rents, energy items, water and food or beverages. ${ }^{24}$

New products and changes of quality may influence in reality observed inflation due to the still existing inaccuracy of our price movement's measures. An important issue is the bias which occurs in the ICPs hold every three years. ${ }^{25}$ House prices (rents) influence rate of inflation depending on the weight of this item in consumer basket. They also have a strong impact on price level, however, all the possible considerations are limited by a lack of data sets.

\subsection{Adjustments of Price Level}

Adjustment of the comparative price level (CPL) in a national economy (denoted) can be written with help of a simple equation as (see Lewis, 2007):

$$
C P L_{i, t}=E X_{i, t}+\pi_{i, t},
$$

where $E X_{i, t}$ is the change of exchange rate and $\pi_{i, t}$ is the rate of domestic inflation of country $i$ for given year $t{ }^{26}$ The relative importance of both channels depends on the regime of exchange rate in a given country. If there is a fixed exchange rate, the adjustment carries out through the inflation channel (i.e. positive inflation differential), in case of a free float the total change of CPL is given by composition resulting from both channels and thus relative proportion (importance) may vary. If there is an inflation target for conduct of monetary policy (this is the case of the Czech Republic, Slovak Republic or Poland), it is simultaneously given the upper limit for inflation channel for a year in the process of price convergence.

The price channel, which influences the national price level in an economy in question, is given by a higher annual rate of domestic inflation. This results from changes of economic structure (for example the so-called selective inflation in case of BS effect), demand and supply factors, on-going process of deregulation of administered prices, changes of taxes (for example changes due to harmonization within the EU), etc. The exchange channel which influences the national price level is given by changes (appreciation) of exchange rate. However, changes of exchange rate may be influenced by both short-lived (i.e. temporary) and long-lived (i.e. fundamental) factors. While transitory factors may lead to temporary disturbances and changes of exchange rate (for example set interest rates in economy resulting in important interest rate differentials), fundamental factors are supposed to be more relevant (for example changes of labour productivity, i.e. GDP per employed person, in a given economy).

24 Balassa-Samuelson effect may reduce inflation in NMS, but bring about equalizing of price levels.

25 This is one of the reasons why the results from ICP rounds are considered to be good measures of international differences at a given time and no over time.

26 Having observations for a given country, the equation 1 does not hold true. It is due to changes in methodology and existence of mismeasurement. Therefore, for calculation on real data it is supposed that the exchange rate term takes into account not only changes of exchange rate, but also errors occurring by measurement. 
Sectoral differences of labour productivity are supposed to be given by influences resulting from the Balassa-Samuelson effect (supply side effect) in neoclassical economic theory. Other explanations are focused on factors linked up with changes of real income of economic subject by different pieces of elasticity of consumption influenced by level of disposable income and its changes (see for example Bergstrand, 1991), influence of relative abundance of inputs (factors of production, i.e. their relative abundance or relative scarcity, see for example Bhagwatti, 1984). There is a large number of other variables which have impact on national price level (the so-called structural factors) and are discussed and often empirically tested in literature (see Čihák, Holub, 2003 ${ }^{27}$; Kleiman, $1993^{28}$; Nestić, 2005 $5^{29}$ ).

\section{Figure 5}

\section{Decomposition of Price Convergence for GDP in the Czech Republic (top) and Estonia (bottom), 1995-2007 (in p.p., EU-12 = 100)}
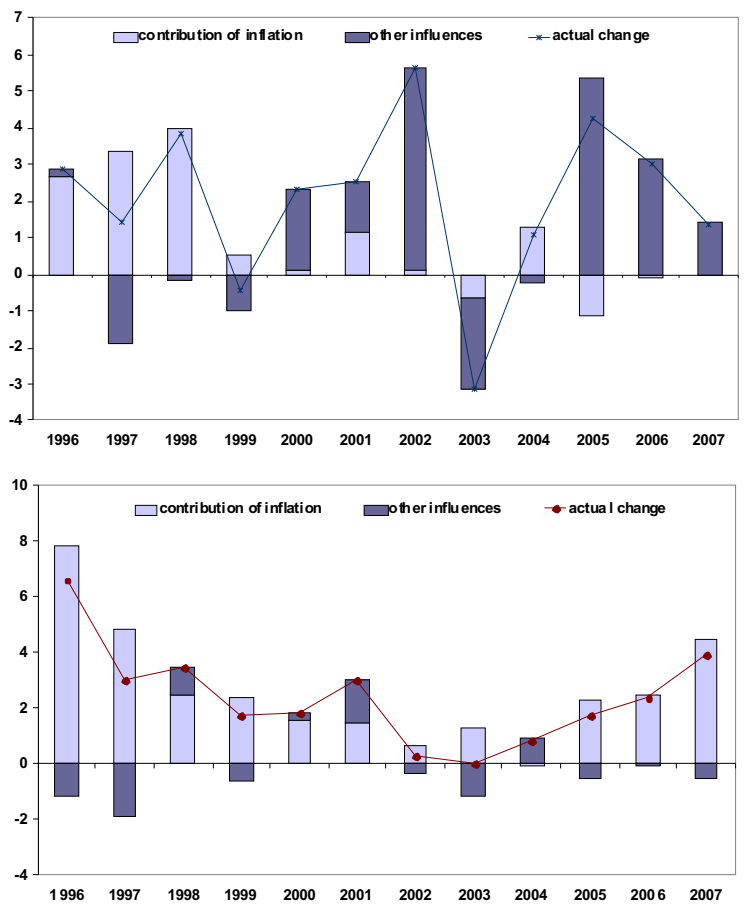

Note: For the explanation of time-series see the text.

Source: EUROSTAT (2008a), prices (downloaded in August, 2008), author's own calculations.

27 The empirical testing of determinants of the national price level based on ECP data set shows that the highest relative importance has level of real income, taxation, labour productivity, etc.

28 Taxation may give rise to increasing prices in domestic economy (in case of shift of tax burden to consumer while having accommodative monetary policy). Influence of government expenditures on prices is supposed to be given by the necessity to finance higher government expenditures either by higher taxes and/or higher ineffectiveness of government production and distribution of goods and services in comparison with private sector.

29 Data stemming form European part of ICP for 1999 confirmed the importance of government revenues and expenditures and labour productivity as the most important factors for determining comparative price level in a given economy. 
Figure 5 shows changes in comparable price level for GDP that were broken down into price development, the influence of other factors (i.e. changes of exchange rate and other influences) in the Czech Republic and in Estonia. These countries were chosen as good examples of the former or the latter type of CPL adjustment. In the case of the Czech economy, one can see that between 1996 and 1998 inflation differential significantly contributed to nominal convergence (the growth of the CPL value). After 1999, the disinflation policies (under new introduced inflation targeting framework in 1998) of the Czech National Bank ( $\breve{\mathrm{NB}}$ ) modified the form of nominal convergence, resulting in negligible or even negative inflation differentials compared to the euro area which confirms the prevailing importance of the exchange rate channel for price convergence. So far the only exceptions to the rule were years 2001 and 2004. The latter example (Estonia) is a country with the fixed exchange rate (currency board arrangement).$^{30}$ This means that without changes of the fixed parity (in our case including methodological changes too) the all adjustment of CPL must go through inflation channel. As a result, Estonian economy showed price convergence based on relatively high inflation differential.

\subsection{Some Thoughts Concerning Structural Aspect of Price Convergence}

Strictly macroeconomic approach to assessing the development of nominal convergence would not suffice since the development of individual parts may be mutually offset. Therefore, an analysis of the individual parts needs to be carried out. It uses data from an international project aimed at comparing prices and actual production in individual countries. Variations from the comparative price level (CPL for GDP) in the NMS-5 compared to the euro area are significantly influenced especially by a different price level of public consumption (it is significantly lower than the price level of GDP). This effect is apparent from the CPL of household consumption expenditures being different from the CPL of actual individual consumption that includes a part of public consumption (which is consumed, however, not paid from the budget of households). Yet the price level of household expenditures is almost identical to the GDP price level (see Table 2).

Within the CPL of total GDP, lower prices of public consumption within the NMS-5 are compensated by other items, especially by higher prices of gross capital formation (this applies especially to machinery that is mainly imported). CPL of investment goods saw the quickest rise as shown by the data for the Czech Republic and other NMS. For example, in 2006, the CPL of machinery and equipment in the Czech Republic reached as much as 96 per cent, in Slovakia even 100 per cent of the euro area level rising by 23 percentage points (17 percentage points) between 1999 and 2006. The CPL of construction rose by significant 15 p.p., respectively 16 p.p. over this period and it is slightly above the CPL for GDP (see Table 2) and, unlike machinery, and these are usually considered non-tradable goods.

Differences in the levels and variability of prices are documented by a comparison of public consumption expenditures with GFCF data (the machinery and equipment item). In the NMS-5 as well as in other transition countries (for example see Nestić, 2005), the price level of machinery and equipment stands at almost 90 per cent of the euro area

30 The Estonian currency - the Estonian kroon (EEK) - was fixed to the deutsche mark in June 1992 $(8: 1)$ and 1999 onwards is pegged to the euro (15.6466:1) 
average (with a correspondingly low coefficient of variation). As opposed to that, in terms of public expenditures, the NMS are at approximately two fifths of the euro area average, showing significant variations among themselves (the indicator is influenced by Slovenia and its government final consumption expenditure level above 67 per cent of the euro area). Similar differences also apply to the goods and services that may be perceived as tradable or non-tradable.

Table 2

Price Levels for Selected Items of GDP, MNS (EU-12 $=100)$

\begin{tabular}{|c|c|c|c|c|c|c|c|c|c|c|c|}
\hline & & $\mathbf{C Z}$ & HU & PL & SI & SK & $\mathbf{E E}$ & $\mathbf{L T}$ & $\mathbf{L V}$ & BG & RO \\
\hline \multirow{9}{*}{1999} & GDP & 43 & 45 & 46 & 70 & 38 & 50 & 41 & 43 & 30 & 31 \\
\hline & Actual Individual Consumption & 40 & 40 & 44 & 70 & 35 & 46 & 38 & 42 & 30 & 31 \\
\hline & Actual Collective Consumption & 32 & 31 & 33 & 65 & 25 & 30 & 25 & 25 & 16 & 17 \\
\hline & GFCF & 57 & 70 & 60 & 73 & 59 & 80 & 67 & 65 & 44 & 40 \\
\hline & - Machinery \& equipment & 73 & 86 & 80 & 92 & 82 & 90 & 85 & 75 & 70 & 67 \\
\hline & - Construction & 44 & 57 & 45 & 56 & 41 & 70 & 53 & 55 & 26 & 24 \\
\hline & Final consumption expenditure & 39 & 39 & 43 & 69 & 34 & 44 & 37 & 40 & 28 & 29 \\
\hline & - Household final consum. expend. & 45 & 46 & 51 & 72 & 40 & 56 & 46 & 51 & 37 & 37 \\
\hline & - Government final consum. expend. & 27 & 26 & 28 & 62 & 23 & 26 & 22 & 21 & 13 & 15 \\
\hline \multirow{9}{*}{2002} & GDP & 53 & 54 & 54 & 71 & 43 & 55 & 47 & 49 & 33 & 36 \\
\hline & Actual Individual Consumption & 50 & 51 & 54 & 71 & 39 & 51 & 45 & 48 & 34 & 35 \\
\hline & Actual Collective Consumption & 41 & 42 & 37 & 67 & 28 & 34 & 29 & 30 & 18 & 19 \\
\hline & GFCF & 68 & 73 & 65 & 71 & 67 & 81 & 70 & 70 & 45 & 53 \\
\hline & - Machinery \& equipment & 89 & 86 & 96 & 90 & 89 & 88 & 90 & 87 & 75 & 81 \\
\hline & - Construction & 52 & 63 & 48 & 58 & 50 & 75 & 56 & 58 & 25 & 35 \\
\hline & Final consumption expenditure & 49 & 49 & 52 & 71 & 38 & 49 & 43 & 45 & 31 & 33 \\
\hline & - Household final consum. expend. & 56 & 57 & 60 & 74 & 44 & 60 & 54 & 56 & 40 & 42 \\
\hline & - Government final consum. expend. & 35 & 36 & 35 & 65 & 26 & 30 & 25 & 27 & 16 & 17 \\
\hline \multirow{19}{*}{2006} & GDP & 58 & 57 & 56 & 71 & 54 & 59 & 51 & 54 & 37 & 48 \\
\hline & Actual Individual Consumption & 55 & 54 & 54 & 72 & 51 & 57 & 49 & 52 & 37 & 49 \\
\hline & Actual Collective Consumption & 45 & 45 & 40 & 60 & 36 & 39 & 34 & 31 & 21 & 30 \\
\hline & GFCF & 74 & 74 & 73 & 75 & 73 & 80 & 77 & 84 & 56 & 65 \\
\hline & - Machinery \& equipment & 96 & 88 & 93 & 92 & 100 & 90 & 86 & 91 & 90 & 96 \\
\hline & - Construction & 59 & 66 & 60 & 64 & 57 & 72 & 71 & 79 & 40 & 47 \\
\hline & Final consumption expenditure & 54 & 52 & 52 & 70 & 49 & 55 & 47 & 49 & 34 & 46 \\
\hline & - Household final consum. expend. & 60 & 58 & 61 & 73 & 57 & 65 & 55 & 59 & 44 & 56 \\
\hline & - Government final consum. expend. & 42 & 41 & 36 & 64 & 34 & 36 & 31 & 29 & 18 & 28 \\
\hline & \multicolumn{11}{|c|}{ Change in 1999-2006 (p.p.) } \\
\hline & GDP & 15 & 12 & 10 & -1 & 15 & 10 & 11 & 11 & -7 & 17 \\
\hline & Actual Individual Consumption & 15 & 13 & 10 & -2 & 16 & 11 & 10 & 10 & -7 & 17 \\
\hline & Actual Collective Consumption & 13 & 14 & -7 & -5 & 12 & -9 & -8 & -6 & -6 & 13 \\
\hline & GFCF & 17 & -4 & 13 & -2 & 15 & -0 & 11 & 19 & 14 & 25 \\
\hline & - Machinery \& equipment & 23 & -2 & 12 & -0 & 17 & -0 & -0 & 15 & 19 & 29 \\
\hline & - Construction & 15 & -9 & 16 & -8 & 16 & -3 & 18 & 24 & 13 & 24 \\
\hline & Final consumption expenditure & 15 & 14 & 10 & -1 & 15 & 11 & 10 & -9 & -7 & 16 \\
\hline & - Household final consum. expend. & 15 & 12 & 10 & -1 & 17 & -9 & -9 & -8 & -7 & 19 \\
\hline & - Government final consum. expend. & 15 & 15 & -8 & -2 & 11 & 10 & -9 & -8 & -6 & 13 \\
\hline
\end{tabular}

Note: GFCF - gross fixed capital formation. The relative price levels of showed items are based on ESA1995 aggregates. Source: EUROSTAT (2008), National Accounts (downloaded in August, 2008), author's own calculations. 
Table 3:

Price Levels for Goods and Services, NMS $(E U-12=100)$

\begin{tabular}{|c|c|c|c|c|c|c|c|c|c|c|c|}
\hline & & $\mathrm{CZ}$ & HU & PL & SI & SK & $\mathbf{E E}$ & LT & LV & BG & RO \\
\hline \multirow{6}{*}{1999} & Total goods & 58 & 64 & 60 & 80 & 56 & 72 & 62 & 65 & 49 & 44 \\
\hline & - consumer goods & 60 & 61 & 61 & 85 & 54 & 68 & 60 & 66 & 52 & 47 \\
\hline & - capital goods & 57 & 70 & 60 & 73 & 59 & 80 & 67 & 65 & 44 & 40 \\
\hline & Total services & 30 & 30 & 34 & 61 & 25 & 34 & 26 & 28 & 19 & 21 \\
\hline & - consumer services & 34 & 33 & 42 & 61 & 27 & 45 & 32 & 37 & 26 & 28 \\
\hline & - government services & 27 & 26 & 28 & 62 & 23 & 26 & 22 & 21 & 13 & 15 \\
\hline \multirow{6}{*}{2002} & Total goods & 71 & 72 & 69 & 79 & 63 & 75 & 67 & 69 & 51 & 53 \\
\hline & - consumer goods & 74 & 72 & 71 & 85 & 61 & 71 & 66 & 66 & 55 & 53 \\
\hline & - capital goods & 68 & 73 & 65 & 71 & 67 & 81 & 70 & 70 & 45 & 53 \\
\hline & Total services & 38 & 40 & 42 & 64 & 28 & 40 & 32 & 35 & 22 & 24 \\
\hline & - consumer services & 42 & 44 & 51 & 63 & 31 & 52 & 41 & 45 & 30 & 34 \\
\hline & - government services & 35 & 36 & 35 & 65 & 26 & 30 & 25 & 27 & 16 & 17 \\
\hline \multirow{13}{*}{2006} & Total goods & 76 & 73 & 74 & 80 & 74 & 77 & 72 & 77 & 61 & 69 \\
\hline & - consumer goods & 78 & 73 & 74 & 85 & 75 & 75 & 69 & 70 & 62 & 71 \\
\hline & - capital goods & 74 & 74 & 73 & 75 & 73 & 80 & 77 & 84 & 59 & 65 \\
\hline & Total services & 43 & 43 & 42 & 64 & 37 & 45 & 35 & 38 & 24 & 34 \\
\hline & - consumer services & 45 & 46 & 48 & 63 & 41 & 56 & 40 & 48 & 30 & 41 \\
\hline & - government services & 42 & 41 & 36 & 64 & 34 & 36 & 31 & 29 & 18 & 28 \\
\hline & \multicolumn{11}{|c|}{ Change in 1999-2006 (p.p.) } \\
\hline & Total goods & 18 & -9 & 13 & -0 & 18 & -5 & 10 & 10 & 12 & 24 \\
\hline & - consumer goods & 18 & 11 & 13 & -1 & 21 & 18 & -8 & -4 & 10 & 24 \\
\hline & - capital goods & 17 & -4 & 13 & -2 & 15 & -0 & 11 & 19 & 14 & 25 \\
\hline & Total services & 13 & 14 & -8 & -2 & 13 & 11 & -9 & 10 & -5 & 13 \\
\hline & - consumer services & 11 & 12 & -7 & -3 & 14 & 10 & -9 & 12 & -4 & 13 \\
\hline & - government services & 15 & 15 & -8 & -2 & 11 & 10 & -9 & -8 & -6 & 13 \\
\hline
\end{tabular}

Note: The relative price levels of goods and services are based on ESA1995 aggregates.

Source: EUROSTAT (2008), National Accounts (downloaded in August, 2008), author's own calculations.

To obtain a somewhat clearer picture of existing and persisting differences, it seems to be enough to compare price levels for total goods and total services which can be divided into two basic groups: consumption and capital goods (services) - see Table $3 .^{31}$ Even though this is a very rough view of the price structures, one can see both significant differences between goods and services and within these subgroups. For some states the difference between subgroups have diminished or persisted, for some even widened, in particular in case of goods (consumer goods and capital goods). It could be due to the fact that this view does not distinguish between tradable and non-tradable goods and services. The issue of tradability seems to be one of the main

31 Total goods can be broken down into non-durable and durable goods whose classification is based on whether the item can be used only once or more than once (repeatedly or continuously in a period more than one year). 
sources of relative wide differences of relative price levels (see general overview of this issue for example Égert, 2007; Žd'árek, Šindel, 2007). Another interesting point is the speed of convergence of individual prices towards the euro area average - countries with relatively high price levels of goods show small changes or any (Slovenia or Hungary, but not for example Estonia), ${ }^{32}$ among the catching-up countries there are the Baltic States or the latest EU newcomers (Bulgaria and Romania).

\section{Empirical Results for the Process of Nominal Convergence}

In this section we try to test the influence of selected factors on price level. We start with simple relationship and we proceed to more advanced approach. Our analysis covers the period from 1995 to 2006 which seems to be relatively short for confirming or refuting hypothesis concerning possible factors influencing price level, in particular in case of transitional economics, such as NMS. The choice of this time span is primarily given by the availability of price level data for most of the EU countries. In addition, if we shorten the period in order to limit the impact of structural influences stemming from the transformation during the 1990 s, our results might have less explanatory power in relation to our aim.

\subsection{Relationship between the Economic and Price Levels}

Economists in their empirical studies pay great attention to the relationship between the economic (GDP measured in purchasing power parity per capita) and comparative price level for GDP (CPL), see Figure 2. This study will also touch on this issue. The theoretical explanation of this relation is based on the BS hypothesis (see Égert, 2003; Čihák and Holub, 2003), the impact of relative availability of production factors in the relevant country (relative abundance or rarity of a particular factor, see for example Bhagwatti, 1984), or differences in the elasticity of consumption and income (see for example Bergstrand, 1991).

Table 4 includes calculation of the cross section regression (OLS) for the price and economic levels (the EU-14 and NMS) obtained from the surveys for 1999 and 2002 and 2005..$^{33}$ (Figure 2 presents the well-known relationship of GDP and CPL for GDP for European countries.) Income per capita is a relatively sufficient factor (explanatory variable) for explaining a major part of the variability in the price level between countries according to an estimate of a simple (linear) regression equation:

$$
C P L_{G D P}=\alpha+\beta \cdot G D P_{P P P}+\varepsilon,
$$

32 Price levels of these items in Hungary were adjusted at the beginning of the 1990s and the price gaps were not due to the nature of economic system so obvious as in case of other NMS- 10 .

33 The result for years between rounds are very similar - for example (without dummy variable) for 2006 was constant $8.5863($ S.E. $=4.7417)$ and the slope $0.9059($ S.E. $=0.0630),=0.895$; or similarly for 2007 was constant $12.691($ S.E. $=5.5953)$ and the slope $0.8640($ S.E. $=0.0732)$, = 0.851 . Inclusion of dummy variable for the NMS was a tool for eliminating some of the observed variability in the sample. This variable was significant and OLS results were somewhat better. This relationship is depicted in Figure 2. 
where $C P L_{G D P}$ is the comparable price level for GDP and $G D P_{P P P}$ is the gross domestic product in purchasing power parity, $\varepsilon$ is the error term. All the values are compared to the euro area average equal to 100 .

$$
C P L_{G D P}=\alpha+\beta \cdot G D P_{P P P}+D_{i}+\varepsilon,
$$

where the notation is the same as in the equation 2 and $D_{i}$ is dummy variable defined for all the NMS is equal to 1 , otherwise 0 .

Table 4

Regression of Comparative Price Level and GDP p.c.

\begin{tabular}{|c|c|c|c|c|c|c|}
\hline \multicolumn{7}{|c|}{ EU-14 + NMS-12 } \\
\hline \multirow[t]{2}{*}{ Dep. var. } & \multicolumn{3}{|c|}{ CPL (EU-12 = 100) } & \multicolumn{3}{|c|}{ CPL (EU-12 = 100) } \\
\hline & 1999 & 2002 & 2005 & 1999 & 2002 & 2005 \\
\hline constant & $\begin{array}{c}7.2465^{*} \\
(3.7755)\end{array}$ & $\begin{array}{l}10.2508^{* *} \\
(3.7526)\end{array}$ & $\begin{array}{l}8.0253^{* * * *} \\
(4.2844)\end{array}$ & $\begin{array}{l}26.0692 * \\
(8.4812)\end{array}$ & $\begin{array}{l}23.7672 * * \\
(8.9813)\end{array}$ & $\begin{array}{l}30.8938^{*} \\
(8.8586)\end{array}$ \\
\hline$\beta$ & $\begin{array}{c}0.9393 * \\
(0.0517)\end{array}$ & $\begin{array}{c}0.9039^{*} \\
(0.0529)\end{array}$ & $\begin{array}{c}0.9118^{*} \\
(0.0580)\end{array}$ & $\begin{array}{c}0.7672 * \\
(0.0906)\end{array}$ & $\begin{array}{c}0.7825^{*} \\
(0.0888)\end{array}$ & $\begin{array}{c}0.7093 * \\
(0.0894)\end{array}$ \\
\hline Dummy & - & - & - & $\begin{array}{l}-12.6239 * * \\
(6.0753)\end{array}$ & $\begin{array}{r}-8.6030 \\
(5.4202) \\
\end{array}$ & $\begin{array}{l}-13.6683^{* * *} \\
(4.7817)\end{array}$ \\
\hline Adj. R2 & 0.9169 & 0.9166 & 0.9084 & 0.9255 & 0.9193 & 0.9244 \\
\hline D-W test & 2.0062 & 1.4442 & 1.7938 & 2.1602 & 1.4354 & 1.8307 \\
\hline $\mathbf{N}$ & 26 & 26 & 26 & 26 & 26 & 26 \\
\hline \multicolumn{7}{|c|}{ EU-14 + NMS-10 } \\
\hline \multirow[t]{2}{*}{ Dep. var. } & \multicolumn{3}{|c|}{ CPL $(E U-12=100)$} & \multicolumn{3}{|c|}{ CPL (EU-12 = 100) } \\
\hline & 1999 & 2002 & 2005 & 1999 & 2002 & 2005 \\
\hline constant & $\begin{array}{r}6.1659 \\
(5.2672)\end{array}$ & $\begin{array}{l}9.9698^{* * *} \\
(5.1534)\end{array}$ & $\begin{array}{r}5.7248 \\
(5.2737)\end{array}$ & $\begin{array}{l}26.3310^{* *} \\
(9.6026)\end{array}$ & $\begin{array}{c}25.1557 * * \\
(10.9876)\end{array}$ & $\begin{array}{c}30.1444 * \\
(10.2330)\end{array}$ \\
\hline$\beta$ & $\begin{array}{c}0.9507 * \\
(0.0654)\end{array}$ & $\begin{array}{c}0.9069^{*} \\
(0.0656)\end{array}$ & $\begin{array}{c}0.9354 * \\
(0.0681)\end{array}$ & $0.7646^{*}$ & $0.7690 *$ & $0.7165^{*}$ \\
\hline Dummy & - & - & - & $\begin{array}{c}-12.6980 * \\
(6.1598) \\
\end{array}$ & $\begin{array}{r}-9.0029 \\
(5.8065) \\
\end{array}$ & $\begin{array}{c}-13.4731^{* *} \\
(5.0318)\end{array}$ \\
\hline Adj. $\mathbf{R}^{2}$ & 0.8967 & 0.8935 & 0.8901 & 0.9064 & 0.8698 & 0.9080 \\
\hline D-W test & 1.9251 & 1.3557 & 1.9166 & 2.1122 & 1.4037 & 1.8746 \\
\hline $\begin{array}{l}\text { no. of } \\
\text { obs. }\end{array}$ & 24 & 24 & 24 & 24 & 24 & 24 \\
\hline
\end{tabular}

Note: Luxembourg omitted. Standard errors in parentheses. * Significance at the 1 per cent level, ${ }^{* *}$ significance at the 5 per cent level, ${ }^{* * *}$ significance at the 10 per cent level.

Source: author's own calculations.

Examination (OLS using White robust method) of the data presented in Table 5 considering for example the estimate according to relation 3 shows that regression (column 4) can account for almost 91 per cent of the variability in the price levels 
between countries. ${ }^{34}$ A zero hypothesis on the non-existence of correlation was rejected based on a 1 per cent level of significance, the normality of residues was confirmed by the Jarque-Bera test, and the heteroscedasticity test does not suggest inappropriate use of the OLS regression. The coefficient of 0.91 (for 2005) shows that an increase in GDP (in PPS) by one point results in a growth in the CPL by approximately 0.9 point in relation to the euro area countries. The detected values in this relation do not differ significantly with a gradually narrowing sample of countries. ${ }^{35}$

\subsection{Additional Factors Influencing Price Level}

As we saw in the Figure 3, some countries showed nominal convergence while having almost the same level of GDP and vice versa. This observed pattern might be an impetus for researchers to think about other factor (variables) influencing the process of nominal convergence. ${ }^{36}$ A wide range of variables that have been discussed and verified in literature (see Section 2.4), see for example Čihák, Holub (2003), Clague (1986), Kleiman (1993), Nestić (2005), can be included among variables influencing the price level in the economy. ${ }^{37}$ This study also includes some of these variables in the regression relation in an attempt to identify factors having impact on the price level apart from GDP per capita and to try to confirm or to disprove the assumptions of these past studies on future development according to the actual data.

Out of the group of possible explanatory variables were selected these that should theoretically determine the price levels and cause their differences and for which needed data were available. The GDP per capita (income level, in relation to the euro area average equals to 100), the openness of a country measured as total export and total import in relation to GDP, population ${ }^{38}$ and total GDP (in PPS) are proxies for the size of a market and an achieved level of economic development respectively, the influence of political system is represented by the public revenues (overall governmental tax revenue in relation to GDP), and the level of public expenditure (general government

34 The relationship is calculated without Luxembourg, which represents an outlier in this group of countries. In this case we therefore arrive at conclusions similar to those presented in the study by Čihák and Holub $(2003,2005)$.

35 The robustness of the relation between the price and economic levels is typically verified on a wider sample of countries (according to the World Bank data). As many studies dedicated to this topic exist, we will omit this verification.

36 Another justification might be the fact that the OLS regression was run for given years and might be viewed as a first approximation of the relationship. Due to the inclusion of only one (aggregate) variable (GDP) it might be subdued with respect to the issue of aggregation. Therefore an approach based on using panel data methods seems to be a next possible step. It also allows us to control for larger set of variables over time and space dimensions.

37 It is possible to divide them into three groups: natural, structural and political factors (Wolszczak-Derlacz, 2008). Natural factors are for example consumer's tastes, culture, structural factors are for example a market structure or price-setting strategies of firms and finally, political factors are influences stemming from different political systems (the fiscal system, trade and non-trade barriers, etc.).

38 The impact of the population size can be included among additional explanatory variables, for discussion see Nestić (2005). 
expenditure in relation to GDP). ${ }^{39}$ The data set covering period 1995-2006 and 26 countries of the EU (Luxembourg was omitted) was taken from EUROSTAT and ECFIN (AMECO). ${ }^{40}$ Due to missing data for some countries this analysis was estimated as unbalanced panel. The estimated panel model can be written as:

$$
\ln \left(C P L_{i, t}\right)=\alpha_{i}+\sum_{i=1}^{k} \beta_{i} \cdot I_{i, t}+\sum_{t=1996}^{2006} \gamma_{t} \cdot d_{t}+\varepsilon_{i, t},
$$

where $C P L_{i, t}$ is the comparative level for GDP, $\alpha_{i}$ is the constant term, $\beta_{i}$ and $\gamma_{i}$ are the vectors of parameters and $I_{i, t}$ is used for all the remaining variables (after using logarithmic transformation), $d_{t}$ are the time dummies (for the time span), $\varepsilon_{i, t}$ is the residual term.

We used the lagged value of explanatory variable (CPL) in this model as well and therefore it can be classified as dynamic. The standard panel data models (Fixed Effects, Pooled OLS, etc.) cannot be used in this case. Due to the underlying data set and dynamic character of the convergence process (which can result in estimator's bias), it was applied a GMM method and a fixed-effect-type estimator with correction for asymptotic bias (see Bruno, 2004). A large number of studies have proposed Arellano-Bond (1991) estimator or Blundell, Bond (1998) method, however, their results are in case of small samples rather questionable. The main problem of this analysis is relatively small number of observations influencing estimated parameters in the given equation 4 (for discussion see for example Wooldridge, 2001). These methods can help with dealing with heteroscedasticity, autocorrelations and endogeneity issue. Both use first differences and lagged values of the endogenous variable as instrument (but their internal procedures for estimation differ). The $\mathrm{AB}$ estimator may result in a weak instruments problem due to the fact that lagged levels are usually not correlated with their differenced counterparts (see for example Prasad et al., 2007). Having not mentioned some of the problems and keeping them in mind, it seems that the most reliable results may be obtained by using the Bruno's method (BB).

The results are shown in Table 5 and each of the applied methods is marked with the first capital letters of their authors. Despite using different methods for estimation, the results show that the main determinant of price level (CPL) is the variable GDP. The CPL (in relation to the euro area average is equal to 100) for given set of countries is influenced by level of GDP per capita both for given year and for a one-year lagged

39 In the case of transfer to final consumers and accommodative monetary policy, tax burden gives rise to an increase in prices (for more details see for example Kleiman, 1993). The impact of (higher) public expenditure leading to (higher) prices is explained by the need to finance increased expenditure through taxes and/or by increased inefficiency in providing governmental services compared to the private sector (X-inefficiency or Baumol's cost disease known as the Baumol Effect). Tax burden is supposed to influence the price levels in developed countries differently from transitive countries because of different relative prices and tax structures; however, we did not control for this possibility in our model.

40 Because of the short time span it was not possible to split the period into two parts, such as prior introducing the euro (1995-1998) and with the euro (1999 onwards). But if one runs the same estimation procedure for the period (1999-2006), i.e. with the euro currency, the results differ very little from specification in Table 5 . 
GDP. This finding supports the very simple results showed in the previous part of the paper. The coefficients have the same sign; however, the impact among models varies considerably. In case of $\mathrm{AB}$ method this coefficient (GDPt) was insignificant.

On the other hand, the indicators of openness (export and import) are statistically insignificant and change their signs, even if the EU countries tend to have relatively high ratios of exports and imports to GDP. It may be possible that the used proxy of openness may be biased due to the fact that it is expressed in national currency converted to euros using annual average exchange rate or that this variable is important for countries of a certain level of economic development. ${ }^{41}$ For the variables of market share (approximated by population and value of GDP in PPS), the applied methods show significant effects of these variables on price level in economy, but signs are different (for LSDV is the coefficient of variable population statistically insignificant). It is also worth noting that methods are exactly different in estimating importance of these determinants (one is important, the other is not).

The impact of variables taking into account the influence of public finance is mixed. Our results show that both variables lead to lower price level (CPL). The coefficient of total expenditure is lower than that of total revenue (not for LSDV) and insignificant (not for BB method) according to standard levels of significance. ${ }^{42}$ In addition, two of the tree methods state that the variable revenue is statistically significant and its impact on price level is negative. The sign of the coefficient is to interpret that an increase in government revenues (either lowering income of economic subjects or increasing prices of goods and services or both) results in reduction of price level. The sign of the coefficient for expenditures is also negative, i.e. the inverse effect than one could expect - higher expenditures are supposed to lead to higher prices of goods (due to the need for balancing the budget or the X-inefficiency). However, the results varied and therefore this channel does not seem to be a simple and stable during the time span and for the set of countries. One of the reasons might be that there were changes in structures of public finances (tax systems) during the observed period (mainly in the middle and the late 1990s) which might distort the links. The second problem might be the definition of the variables - total revenues and total expenditures - consisting of different

41 The coefficients of these variables were not in our analysis significant at all the (common) levels of probability. However, their signs showed that the theoretical relationship might hold, i.e. export leads to higher, import to lower price level in economy. One of the reasons may be that there is a different level of openness of countries within the European Union that could influence the result. As the openness does not have a significant effect in regression, even when different definitions are applied, it seems that this impact was only significant until a certain level of trade flows was achieved in Europe and once achieved, there is no significant impact on price differentials among the countries.

42 On the contrary, the commonly used explanatory variables, such as value added tax (VAT) that could explain some price differences because of its relatively high share (standard VAT) in total price for some goods as well as indirect taxes or taxes on import and consumption were insignificant. 
streams of flows ${ }^{43}$ that might bias the coefficient. ${ }^{44}$ Time dummies for given years are not shown. ${ }^{45}$

One should not forget that there is a trade-off for GMM method: the greater the lags, the more information is used, however, a greater lag can result in overfitting and weak instrumentation. For checking the robustness of our result the standard tests were used. Hansen (Sargan) test for overidentifying restrictions does not reject the null hypothesis, but it could be due to the bad power of this test (small number of observations and a large number of coefficients and dummies). The Arellano-Bond test for serial correlation shows mixed results too. The first-order serial correlation rejects the null hypothesis of no first-order serial correlation (only BB method); however, it does not reject the null hypothesis of no second-order serial correlation (for both methods). The Hausman test does reject the null hypothesis and therefore, the LSDV model seems to be a right choice.

The results from our empirical analysis show that direction and power of individual variables on price level are ambiguous. One might surmise various reasons, including some related to the model specification or to the applied methods. The interpretation of our result should be done with this in mind. It may be viewed as a first step towards the way finding determinants of price level. In spite of this fact, most of the explanatory power comes from GDP and population (the variables for openness are not significant or the impact of government revenues and expenditures are not certain). Relatively difficult is the issue of exchange rate. From theoretical point of view exchange rate is one of the two determining factors for CPL and therefore one of the most influential variables. However, it is very difficult to prove its impact on price level. Empirical studies show different results based on the applied method and expression of exchange rate regimes or measures of volatility of exchange rates (see Broda, 2002; Wolszczak-Derlacz, 2008) or that its effect on price level is not so direct as supposed (for example see Nestić, 2005). ${ }^{46}$

44 For example the variable revenues consist of total government revenues including effects of changes in VAT and/or income taxes. The coefficient for VAT should be positive, because it increases the price of goods. An increased income tax lowers the disposable income (ceteris paribus) and its impact on price of goods is uncertain (government may use revenues for other purposes than people). For extended discussion of various aspects price settings and price structures see for example Égert (2007).

45 One may think about the consolidation of public finances in the EU countries before launching the euro and a potential threat of an application of the well-known numerical limits on public deficit and public debt due to the Stability and Growth Pact and/or reforms of public finances in the NMS (for example the Czech Republic in 2003, Poland and Slovakia in 2004).

45 Four out of nine time dummies were significant (at 10 per cent level, three even at 5 per cent level). It is possible to think about external shocks (for example volatility of exchange rate) that influenced the price levels in the analysed period.

46 This result may be biased due to fact that this study was based on a larger set of countries and did not use methods for panel data. Another issue is the set of countries (the euro area members or countries without the euro area) and the exchange rate arrangements (fixed or float). 
Table 5:

Panel Regression of the Comparative Price Level for GDP $(E U-12=100)$

\begin{tabular}{|c|c|c|c|c|c|c|}
\hline & \multicolumn{2}{|c|}{$\mathbf{A B}$} & \multicolumn{2}{|c|}{ BB } & \multicolumn{2}{|c|}{ LSDV } \\
\hline \multirow[t]{2}{*}{ Depend. var. } & \multicolumn{6}{|c|}{ CPL $(E U-12=100)$} \\
\hline & coefficient & p-value & coefficient & p-value & coefficient & p-value \\
\hline Constant & $\begin{array}{r}0.011 \\
(0.005) \\
\end{array}$ & 0.015 & $\begin{array}{r}0.014 \\
(0.037) \\
\end{array}$ & 0.002 & $\begin{array}{l}- \\
- \\
\end{array}$ & - \\
\hline$C P L_{t-1}$ & $\begin{array}{r}0.428 \\
(0.148) \\
\end{array}$ & 0.005 & $\begin{array}{r}0.946 \\
(0.022) \\
\end{array}$ & 0.000 & $\begin{array}{r}0.721 \\
(0.043) \\
\end{array}$ & 0.000 \\
\hline$G D P_{t} p . c$. & $\begin{array}{l}-0.109 \\
(0.142)\end{array}$ & 0.445 & $\begin{array}{l}-0.234 \\
(0.872) \\
\end{array}$ & 0.007 & $\begin{array}{l}-0.127 \\
(0.678)\end{array}$ & 0.056 \\
\hline$G D P_{t-1}$ p.c. & $\begin{array}{r}0.247 \\
(0.060) \\
\end{array}$ & 0.000 & $\begin{array}{r}0.189 \\
(0.898) \\
\end{array}$ & 0.027 & $\begin{array}{r}0.236 \\
(0.067) \\
\end{array}$ & 0.000 \\
\hline Export & $\begin{array}{r}0.00023 \\
(0.001) \\
\end{array}$ & 0.660 & $\begin{array}{r}0.00007 \\
(0.001) \\
\end{array}$ & 0.882 & $\begin{array}{r}0.00062 \\
(0.001) \\
\end{array}$ & 0.348 \\
\hline Import & $\begin{array}{r}-0.0074 \\
(0.001) \\
\end{array}$ & 0.260 & $\begin{array}{r}-0.00053 \\
(0.001) \\
\end{array}$ & 0.311 & $\begin{array}{r}-0.00197 \\
(0.001) \\
\end{array}$ & 0.759 \\
\hline Population & $\begin{array}{r}0.000009 \\
(0.000) \\
\end{array}$ & 0.098 & $\begin{array}{r}-0.000046 \\
(0.000) \\
\end{array}$ & 0.021 & $\begin{array}{r}0.00037 \\
(0.000) \\
\end{array}$ & 0.429 \\
\hline$G D P_{t}(\mathrm{PPS})$ & $\begin{array}{r}-0.000011 \\
(0.000)\end{array}$ & 0.024 & $\begin{array}{r}0.000027 \\
(0.000)\end{array}$ & 0.072 & $\begin{array}{r}0.0000367 \\
(0.000) \\
\end{array}$ & 0.042 \\
\hline Expenditures & $\begin{array}{r}-0.00076 \\
(0.013) \\
\end{array}$ & 0.560 & $\begin{array}{r}-0.000915 \\
(0.001) \\
\end{array}$ & 0.083 & $\begin{array}{r}-0.000257 \\
(0.001) \\
\end{array}$ & 0.778 \\
\hline Revenues & $\begin{array}{r}-0.0037 \\
(0.006)\end{array}$ & 0.000 & $\begin{array}{r}-0.00091 \\
(0.001) \\
\end{array}$ & 0.457 & $\begin{array}{r}-0.000197 \\
(0.000)\end{array}$ & 0.000 \\
\hline \multirow[t]{2}{*}{ No. of obs. } & 257 & $\begin{array}{r}\text { No. of } \\
\text { groups }=27\end{array}$ & 284 & $\begin{array}{r}\text { No. of } \\
\text { groups }=27\end{array}$ & 284 & $\begin{array}{c}\text { No. of } \\
\text { groups }=27\end{array}$ \\
\hline & Wald $\chi^{2}(18)$ & $\begin{array}{r}458.86 \\
(0.000) \\
\end{array}$ & Wald $\chi^{2}(19)$ & $\begin{array}{r}84341.18 \\
(0.000) \\
\end{array}$ & Hausman $\chi^{2}(8)$ & $\begin{array}{r}17.88 \\
(\operatorname{Pr} .>\mathrm{z}=0.000) \\
\end{array}$ \\
\hline \multirow{3}{*}{$\begin{array}{l}\text { Arellano- } \\
\text { Bond test }\end{array}$} & 1. dif. & $\begin{array}{c}\mathrm{z}=-1.17 \\
(\operatorname{Pr}>\mathrm{z}=0.2435)\end{array}$ & 1. dif. & $\begin{array}{c}\mathrm{z}=-2.63 \\
(\operatorname{Pr} \mathrm{\gamma}=\mathrm{z}=0.0080)\end{array}$ & & \\
\hline & 2. dif. & $\begin{array}{r}z=0.95 \\
(\operatorname{Pr} .>z=0.3436)\end{array}$ & 2. dif. & $\begin{array}{r}z=-0.70 \\
(\text { Pr. }>z=0.4850)\end{array}$ & & \\
\hline & $\begin{array}{r}\text { Hansen } \\
\chi^{2}(127)\end{array}$ & $\begin{array}{c}13.59 \\
\left(\operatorname{Pr}>\chi^{2}=1.000\right)\end{array}$ & $\begin{array}{l}\text { Hansen } \\
\chi^{2}(121)\end{array}$ & $\begin{array}{c}8.26 \\
\left(\operatorname{Pr} .>\chi^{2}=1.000\right)\end{array}$ & & \\
\hline
\end{tabular}

Note: Luxembourg omitted. Standard errors in parentheses. Descriptions of individual variables see text. Time dummies are not showed. The equation 4 has been estimated with StataSE 9.2 software.

Source: author's own calculations.

This type of analysis that we showed is linked with some problems. One of them might be the sample size and inclusion of old and new EU member states. In particular, the issue of exchange rate parameter seems to be one of the potential candidates. All the EU states (without Luxembourg) were included because analysis only for the NMS was 
even less powerful due to lack or shortage of data sets. The same issue was for example the possibility of inclusion of parameter taking into account differences in labour productivity for tradable and non-tradable sector of national economy.

\section{Conclusions}

Price convergence is a part of the process of structural changes in the economy and is (inextricable) intertwined with on-going real convergence. This process includes an adjustment of price and wage levels of catching-up economies with the European average. Two transmission mechanisms are involved in nominal convergence: inflation differential and appreciation of the nominal currency exchange rate.

The price channel influences the national price level due to the higher annual rate of domestic inflation and this leads to changes of economic structure (selective inflation), etc. The exchange channel has an effect on the national price level owing to changes (appreciation) in exchange rate. However, changes in exchange rate may be influenced by both temporary and fundamental factors. While transitory factors bring about temporary disturbances and changes in exchange rate, fundamental factors are expected to be more relevant. The movements of exchange rates rather than the inflation differential influenced the adjustment of price levels in the case of countries, such as the Czech Republic or Slovakia after 2000. On the other hand, currency board in Estonia has put more emphasis on the inflation channel.

The significant divergence of the price level in the economy from the value expected in relation to the achieved economic level could be a potential source of difficulties for selected NMS within ERM II period or then within the euro area posing a threat for single monetary policy and its appropriateness, such as the current situation of Slovenia and maybe Slovakia. This fact is a relatively serious economic problem not only for the present times, but also especially for future development of the economy as a whole. A number of factors that may influence this status have been mentioned in this paper, as the frequently discussed issue of price regulation is not sufficient.

Our analysis based on employing various econometric methods showed that the most important factor for nominal (price) convergence was the real GDP. Having extended the number of explanatory variables (for example development of exchange rate or indicators of openness of the economy), some variables were statistically insignificant (the measures of the openness) while others seemed to have ambiguous impact on CPL (the government revenues and expenditures). It might have been owing to short time-series that were available. Therefore, it is very difficult to draw some firm and clear (and certain) conclusion about the relationship, apart from the significant influence of real GDP.

The process of nominal convergence is subject to a number of structural specifics, especially when looking separately at tradable and non-tradable sectors as well as individual items of GDP expenditures and various categories of household consumption expenditures. A gradual increase in particular in the prices of non-tradable commodities, where the price level tends to be lower in less developed countries, will result in direct or indirect pressure on manufacturing costs of companies (growing prices of inputs and growing wage costs) and force those companies that wish to survive in the competition to improve their productivity. Nevertheless, estimating exactly how 
long the process of price convergence may take is very difficult for a large number of reasons (especially due to the difference between tradable and non-tradable goods). The experience of the less developed countries that joined the European Union in the 1980s or that of the NMS using the euro will be interesting to study. Because the NMS share many common economic characteristics but they also have some significant differences in relationship between nominal and real convergence, suitable timing for adopting euro in each of the countries is therefore a very individual issue with no universal solution.

\section{References}

Allington, N. F. B., Kattuman, P. A., Waldmann, F. A. (2005), "One Market, One Money, One Price?" International Journal of Central Banking, 2005, 1 (3), pp. 73-115.

Arellano, M., Bond, S. (1991), "Some Tests of Specification for Panel Data: Monte Carlo Evidence and an Application to Employment Equations." Review of Economic Studies, 2005, 58 (2), pp. 277-297.

Backé, P., Fidrmuc, J., Reininger, T., Schardax, F. (2003), "Price Dynamics in Central and Eastern European EU Accession Countries." Emerging Markets Finance and Trade, 2003, 39 (3), pp. 42-78.

Bergstrand, J. H. (1991), "Structural Determinants of Real Exchange Rates and National Price Levels: Some Empirical Evidence." American Economic Review, 1991, 81 (1), pp. 325-334.

Bhagwatti, J. N. (1984), Why Are Services Cheaper in the Poorer Countries? Economic Journal, 1991, 94 (374), pp. 279-286.

Blundell, R., Bond, S. (1998), "Initial Conditions and Moment Restrictions in Dynamic Panel Data Models." Journal of Econometrics, 1998, 87 (1), pp. 115-143.

Broda, Ch. (2002), "Uncertainty, Exchange Rate Regime and National Price Levels." [FRB Staff Reports No. 151]. New York: Federal Reserve Bank of New York, 2002.

Brook, A-M. (2005), "The Challenges of EMU Accession Faced by Catching-up Countries: A Slovak Republic Case Study." [OECD Economic Department Working Paper No. 444]. Paris: OECD, 2005.

Bruno, G. S. F. (2004), "Approximating the Bias of the LSDV Estimator for Dynamic Unbalanced Panel Data Models." [CESPRI Working Paper No. 159]. Milano: Bocconi University, 2004.

Buseti, F., Forni, L., Harvey, A., Venditti, F. (2006), "Inflation Convergence and Divergence within the European Monetary Union." [ECB Working Paper No. 574]. Frankfurt am Main: ECB, 2006.

Clague, C. K. (1986), "Determinants of National Price Levels: Some Empirical Results." Review of Economics and Statistics, 1986, 68 (2), pp. 302-323.

Crucini, M. J., Telmer. C. I., Zachariadis, M. (2005), "Understanding European Real Exchange Rates." American Economic Review, 2005, 95 (3), pp. 724-738.

Čihák, M., Holub, T. (2003), "Price Convergence to the EU: What Do the 1999 ICP Data Tell Us?" [CNB Working Paper No. 2]. Prague: ČNB, 2003.

Čihák, M., Holub, T. (2005), "Price Convergence in EU-Accession Countries: Evidence from the International Comparison." Économie internationale, 2005, 102 (2), pp. 59-82.

De Grauwe, P., Schnabel, G. (2005), "Nominal Versus Real Convergence - EMU Entry Scenarios for the New Member States." Kyklos, 2005, 58 (4), pp. 537-555.

Dobrinsky, R. (2003), "Convergence in Per Capita Income Levels, Productivity Dynamics and Real Exchange Rates in the EU Acceding Countries." Empirica, 2003, 30 (3), pp. 305-334.

Dobrinsky, R. (2006), "Catch-up Inflation and Nominal Convergence: The Balancing Act for New EU Entrants." Economic Systems, 2006, 30 (4), pp. 424-442.

Dreger, Ch., Kholodilin, K., Lommatzsch, K., Slacalek, J., Wozniak, P. (2007), "Price Convergence in the Enlarged Internal Market." [EC Economic Paper No. 292]. Brussels: European Commission, 2007.

EC (2006), "Enlargements, Two Years After: An Economic Evaluation." [Occasional Paper No. 24]. Brussels: European Commission, 2006.

EC (2007), "Communication from the Commission to the Council, the European Parliament, the European Economic and Social Committee, the Committee of the Regions and the European Central 
Bank." [Fifth report on the practical preparations for the future enlargement of the euro area, $\operatorname{COM}(2007) 434$ final]. Brussels: European Commission, 2007.

ECB (2005), Monthly Bulletin. [No. 5/2005]. Frankfurt am Main: ECB, 2005.

ECB (1999), Monthly Bulletin. [No. 44]. Frankfurt am Main: ECB, 1999.

ECFIN (2007), Statistical Annex to European Economy. Brussels: DG ECFIN, 2007.

ECFIN (2007), AMECO Database. Brussels: DF ECFIN, 2007.

Engel, C., Rogers, J. H. (2004), "European Product Market Integration after the Euro." Economic Policy, 2004, 19, Issue 39, pp. 347-384.

Égert, B. (2003), "Nominal and Real Convergence in Estonia: The Balassa-Samuelson (Dis)Connection." [WDI Working Paper No. 556]. Ann Arbor: The William Davidson Institute, 2003.

Égert, B. (2007), "Real Convergence, Price Level Convergence and Inflation Differentials in Europe." [WDI Working Paper No. 895]. Ann Arbor: The William Davidson Institute, 2007.

EUROSTAT (2008), Database Prices. Luxembourg: EUROSTAT, 2008. http://epp.eurostat.ec.europa.eu/.

EUROSTAT (2008a), Database National Accounts. Luxembourg: EUROSTAT, 2008. http://epp.eurostat.ec.europa.eu/.

EUROSTAT (2008b), Database Structural Indicators. Luxembourg: EUROSTAT, 2008. http://epp.eurostat.ec.europa.eu/.

Faber, R. P., Stockman, A. C. J. (2007), "A Short History of Price Level Convergence in Europe: A Reconstruction." [Paper prepared for the 22nd EEA Congress]. Budapest: 2007 (mimeo).

Goldberg, P., K., Verboven, F. (2005), "Market Integration and Convergence to the Law of One Price: Evidence from the European Car Market." Journal of International Economics, 2005, 65 (1), pp. 49-73.

Hájek, M. (2008), "Ekonomický růst v ČR a nových členských zemích Evropské unie v období 1995-2006." (Economic Growth in the Czech Republic and New Member States of the European Union in the Period 1995-2006.) Politická ekonomie, 2008, 56 (4), pp. 435-448.

Kleiman, E. (1993), "Taxes and the Price Level: A Further Examination of PPP Hypothesis." [IMF Working Paper No. 5]. Washington: IMF, 1993.

Kočenda, E., Kutan, A. M., Yigit, T. M. (2006), "Pilgrims to the Eurozone: How Far, How Fast?" Economic Systems, 2006, 30, Issue 4, pp. 311-327.

Kravis, I., Lipsey, R. (1988), "National Price Levels and the Prices of Tradables and Non-tradables." American Economic Review, 1988, 78 (2), pp. 474-478.

Larraín, F. B., Sachs, J. D. (1993), Macroeconomics in the Global Economy. New York: Harvester Wheatsheaf. ISBN 0-7450-0608-6.

Lewis, J. (2007), "Hitting and Hoping? Meeting the Exchange Rate and Inflation Criteria During a Period of Nominal Convergence." [DNB Working Paper No. 130]. Amsterdam: De Nederlandsche Bank, 2007.

López-Salido, J. D., Quirós, G. P. (2006), "Comparative Analysis: Real Convergence, Cyclical Synchrony and Inflation Differentials." In: The analysis of the Spanish Economy: Data, Instruments and Procedures. Madrid: Banco de Espaňa, pp. 409-433, ISBN 84-7793-830-X.

Lutz M. (2003), "Price Convergence under EMU? First Estimates." [Department of Economic Working Paper No. 8]. St. Gallen: University of St. Gallen, 2003.

Lutz, M. (2004), "Pricing in Segmented Markets, Arbitrage Barriers and the Law of One Price: Evidence from the European Car Market." Review of International Economics, 2004, 12 (3), pp. 456-475.

Mihaljek, D., Klau, M. (2003), "The Balassa-Samuelson Effect in Central Europe: A Disaggregated Analysis." [BIS Working Paper No. 143]. Basel: BIS, 2003.

Nestić, D. (2005), "Price Level Convergence: Croatia, Transition Countries and the EU." [CNB Working Paper No. W-13]. Zagreb: Croatian National Bank, 2005.

Officer, L. H. (1976), "The Purchasing-Power-Parity. Theory of Exchange Rates: A Review Article." IMF Staff Paper, 23 (1), pp. 1-60.

Pazour, M. (2006), "Dynamika konvergence cenové úrovně a strategie přistoupení k eurozóně." (Price Level Convergence Dynamics in the CR and the Accession Strategy to the Eurozone.) Politická ekonomie, 2006, 54 (6), pp. 802-815.

Prasad, E. S., Rajan, R. G., Subramanian, A. (2007), "Foreign Capital and Economic Growth." [NBER Working Paper No. 13619]. Cambridge: NBER, 2007. 
Schadler, S., Drummond, P., Kuijs, L., Murgasova, Z., Van Elkan, R. (2005), "Adopting the Euro in Central Europe. Challenges of the Next Step in European Integration." [IMF Occasional Paper No. 234]. Washington: IMF, 2005.

Skořepa, M. (2001), "K rozdílům v cenových hladinách mezi ČR a Německem." (On the Differences in Price Levels between the Czech Republic and Germany.) Finance a úvěr, 2001, 51 (6), pp. 350-363.

Slavík, C. (2007), "Reálná konvergence České republiky k Evropské unii v porovnání s ostatními novými členskými zeměmi." (Real Convergence of the Czech Republic to the EU in Comparison with the Other New Member Countries.) Politická ekonomie, 2007, 55 (1), pp. 23-40.

Taylor, A. M., Taylor, M. P. (2004), "The Purchasing Power Parity Debate." [NBER Working Paper No. 10607]. Cambridge: NBER, 2004.

UBS (2006), "Prices and Earnings. A Comparison of Purchasing Power around the Globe - 2006 Edition." Zurich: UBS Wealth Management Research, 2006.

Viner, J. (1937), Studies in the Theory of International Trade. London: George Allen \& Unwin Ltd. 1937.

Vintrová, R. (2007), "Reálná a nominální konvergence v zemích středoevropské pětky." (Real and Nominal Convergence of the CEE Countries.) Politická ekonomie, 2007, 55 (2), pp. 206-225.

Vintrová, R., Žd'árek, V. (2007), "Links between Real and Nominal Convergence in the New EU Member States: Implications for the Adoption of Euro." Ekonomický časopis /Economic Journal, 2007, 55 (5), pp. 1-20.

Vintrová, R., Žd'árek, V. (2007a), "Nominal Convergence." In: Kadeřábková, A. et al., The Competitiveness Yearbook - Czech Republic 2006-2007. Prague: Linde 2007, pp. 29-35. ISBN 978-80-86131-78-8.

WB (2007), "2005 International Comparison Program. Preliminary Results." Washington: World Bank, 2007. http://siteresources.worldbank.org/ICPINT/Resources/ICPreportprelim.pdf.

Wolszczak-Derlacz, J. (2008), "Price Convergence in the EU - an Aggregate and Disaggregate Approach." International Economics and Economic Policy, 2008, 5, Nos. 1-2, pp. 25-47.

Wooldridge, J. M. (2002), Econometric Analysis of Cross Section and Panel Data. Cambridge: MIT Press, 2002. ISBN 0-262-23219-7.

Žd'árek, V., Šindel, J. (2007), "Real and Nominal Convergence and the New EU Member States Actual State and Implication." Prague Economic Papers, 2007, 14 (3), pp. 197-215. 